\title{
Evaluation of black carbon emission inventories using a Lagrangian dispersion model - a case study over southern India
}

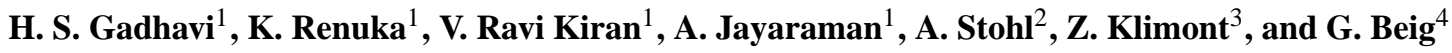 \\ ${ }^{1}$ National Atmospheric Research Laboratory, Gadanki, 517 112, India \\ ${ }^{2}$ Norwegian Institute for Air Research, Instituttveien 18, 2027 Kjeller, Norway \\ ${ }^{3}$ International Institute for Applied Systems Analysis, 2361 Laxenburg, Austria \\ ${ }^{4}$ Indian Institute of Tropical Meteorology, Dr. Homi Bhabha Road, Pashan, Pune, 411 004, India \\ Correspondence to: H. S. Gadhavi (harish.gadhavi@gmail.com, harish@narl.gov.in)
}

Received: 26 June 2014 - Published in Atmos. Chem. Phys. Discuss.: 27 October 2014

Revised: 14 January 2015 - Accepted: 16 January 2015 - Published: 10 February 2015

\begin{abstract}
We evaluated three emission inventories of black carbon (BC) using Lagrangian particle dispersion model simulations and $\mathrm{BC}$ observations from a rural site in southern India (Gadanki; $13.48^{\circ} \mathrm{N}, 79.18^{\circ} \mathrm{E}$ ) from 2008 to 2012 . We found that 93 to $95 \%$ of the $\mathrm{BC}$ load at the observation site originated from emissions in India and the rest from the neighbouring countries and shipping. A substantial fraction (33 to $43 \%$ ) of the BC was transported from northern India. Wet deposition is found to play a minor role in reducing $\mathrm{BC}$ mass at the site because of its proximity to $\mathrm{BC}$ sources during rainy season and relatively short rainy season over western and northern parts of India. Seasonally, the highest $\mathrm{BC}$ concentration (approx. $3.3 \mu \mathrm{g} \mathrm{m}^{-3}$ ) is observed during winter, followed by spring (approx. $2.8 \mu \mathrm{g} \mathrm{m}^{-3}$ ). While the model reproduced well the seasonal cycle, the modelled BC concentrations are significantly lower than observed values, especially in spring. The model bias is correlated to fire radiative power - a proxy of open biomass burning activity. Using potential emission sensitivity maps derived using the model, we suggest that underestimation of $\mathrm{BC}$ mass in the model during spring is due to the underestimation of BC fluxes over southern India (possibly from open-biomass-burning/forest-fires). The overall performance of the model simulations using three different emission inventories (SAFAR-India, ECLIPSE and RETRO) is similar, with ECLIPSE and SAFAR-India performing marginally better as both have about $30 \%$ higher emissions for India than RETRO. The ratio of observed to modelled annual mean BC concentration was estimated as 1.5 for SAFAR, 1.7 for ECLIPSE and 2.4 for RETRO.
\end{abstract}

\section{Introduction}

Black carbon (BC) is a component of soot, which is responsible for the absorption of visible light (Yasa et al., 1979). It is emitted into the atmosphere as a consequence of incomplete combustion processes like biofuel burning, running of inefficient diesel engines, forest fires, etc. Unlike other aerosols, $\mathrm{BC}$ aerosols are responsible for positive radiative forcing which is comparable to forcing by major greenhouse gases (Haywood and Ramaswamy, 1998; Jacobson, 2001; Bond et al., 2013). Presence of $B C$ in the atmosphere also affects the hydrological cycle of Earth and regional climate (Ackerman et al., 2000).

Understanding the sources of $\mathrm{BC}$, their geographical distribution and future changes is therefore important to improve climate modelling and would support development of policies exploring climate co-benefits of air pollution regulation controlling sources of BC. However, global BC emissions estimates are highly uncertain. Dickerson et al. (2002) estimated BC emissions of South Asia at between 2 and $3 \mathrm{Tg}$ in year 1999 using the $\mathrm{BC} / \mathrm{CO}$ ratio - a factor of 2 to 3 higher than bottom-up BC inventories, suggesting significant underestimation of $\mathrm{BC}$ sources in South Asia. The range of global $\mathrm{BC}$ emissions has been reported as 4 to $13 \mathrm{Tg} \mathrm{yr}^{-1}$ (Bond et al., 2013). Emissions from India contribute 7 to $14 \%$ of global BC emissions (Bond et al., 2004; Schultz and Rast, 2007; Klimont et al., 2009, 2015a, b) and observed $\mathrm{BC}$ concentrations over India are significantly higher than in other regions (Suresh Babu and Moorthy, 2002; Suresh Babu et al., 2002; Ganguly et al., 2005, 2006a, b; Jayara- 


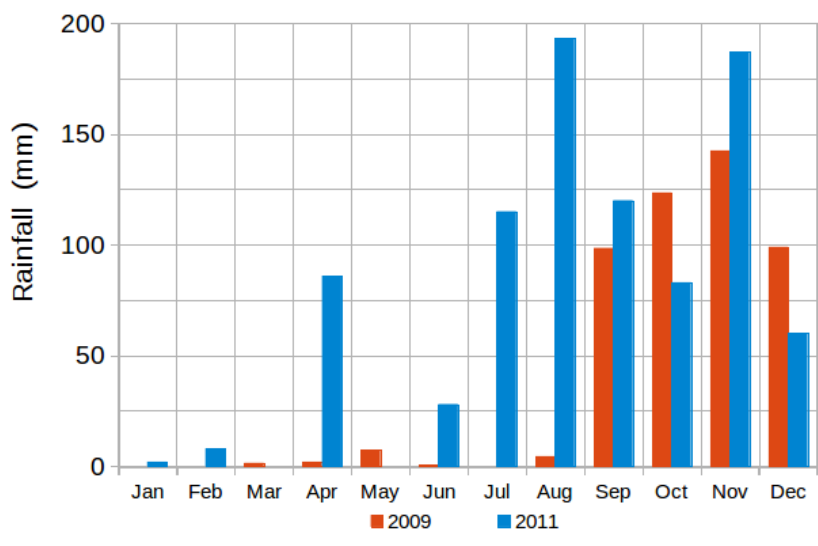

Figure 1. Monthly precipitation amounts over Gadanki during 2009 and 2011.

man et al., 2006; Ramachandran and Rajesh, 2007; Beegum et al., 2009; Gadhavi and Jayaraman, 2010; Ramachandran and Kedia, 2010; Vinoj et al., 2010; Raghavendra Kumar et al., 2011). Model-predicted BC concentrations over India are generally found to be factor of 2 to 6 lower than those observed (Ganguly et al., 2009; Nair et al., 2012; Bond et al., 2013; Moorthy et al., 2013). This raises the question whether the observed high $\mathrm{BC}$ concentrations over India are the result of transport from other places, relatively inefficient removal of $\mathrm{BC}$ compared to elsewhere, or underestimation of emissions from India.

In this paper we examine the emission inventories RETRO (Schultz et al., 2007; Schultz and Rast, 2007), ECLIPSE (Klimont et al., 2013, 2015a, b) and SAFAR-India (Sahu et al., 2008) using the particle dispersion model FLEXPART (Stohl et al., 1998, 2005) driven by observed meteorological fields and suggest possible causes of the underestimation of BC concentrations by models over India.

\section{Site description}

Observations of $\mathrm{BC}$ have been carried out at the climate observatory of the National Atmospheric Research Laboratory in Gadanki. Gadanki $\left(13.48^{\circ} \mathrm{N}\right.$ and $79.18^{\circ} \mathrm{E}, 365 \mathrm{~m}$ a.s.l.) is a typical rural site in southern India, with no major industrial activities in the near vicinity. Gadanki has tropical wet climate and experiences a prolonged rainy season from both southwest and northeast monsoons unlike the northern and western parts of India. Monthly rainfall patterns over Gadanki for the years 2009 and 2011 are shown in Fig. 1. February to May is mostly dry. The rainy season starts in June and goes on until December with short lulls in between. The maximum rainfall over Gadanki in the year 2009 was observed during November whereas in the year 2011 it occurred during August with a comparable rain amount in November. The year 2009 was officially declared as a drought year for

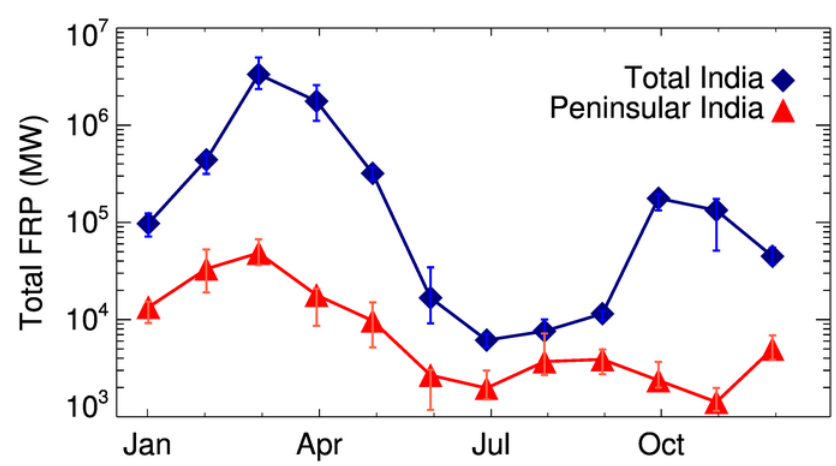

Figure 2. Monthly median fire radiative power values obtained from MODIS satellite for whole India and peninsular India (south of $18^{\circ} \mathrm{N}$ latitude).

the state of Andhra Pradesh (in which Gadanki is located), whereas 2011 was a normal year.

Open biomass burning has a well characterized seasonal cycle over India (Joseph et al., 2009). Fire radiative power (FRP) is a measure of radiative energy emitted per unit time in a fire event. Its value is proportional to amount of material being burnt in the fire event. Fires detected using MODIS satellite sensor are characterized by FRP values using an empirical formula based on difference in brightness temperature at $4 \mu \mathrm{m}$ with respect to non-fire pixels in the vicinity (Giglio et al., 2003; Justice et al., 2006; Davies et al., 2009). In Fig. 2, long-term (2000-2013) monthly median FRP values over the southern part of India (south of $18^{\circ} \mathrm{N}$ latitude; henceforth referred as Peninsular India) and over the whole of India are shown. FRP is high during February to May and low during June to September. The largest differences in the seasonal variation of FRP between Peninsular India and whole India occur during October to November. As mentioned before, Peninsular India where the observations are carried out experiences two rainy seasons whereas North, West and Central India experiences only one rainy season. The northeast monsoon brings rain over Peninsular India during winter and reduces the number of fire events and hence FRP whereas absence of rain results in high FRP over other parts of India.

\section{Instrumentation and data}

Equivalent $\mathrm{BC}(\mathrm{EBC})$ concentrations are measured using an aethalometer (Model AE31; Magee-Scientific, USA), which has seven wavelength channels centred at 370, 470, 520, 590, 660,880 and $950 \mathrm{~nm}$. In this study, we report EBC values based on $880 \mathrm{~nm}$ channel data as it has minimum interference from other species and is considered to be the standard channel for BC measurement with this technology (Hansen, 2005). Details of the instrument and the typical set-up used at Gadanki are reported in an earlier study (Gadhavi and Jayaraman, 2010). The ambient air is drawn with a typical flow rate 
of $2.9 \mathrm{~L} \mathrm{~min}^{-1}$ for five minutes and passes through a quartz fibre filter fitted in an optical chamber. Changes in transmission of light through filter paper is monitored which is affected by accumulated deposition of light-absorbing particles on the filter paper. The changes in absorption coefficient of filter paper are converted to equivalent BC mass by dividing it with mass absorption cross-section $0.166 \mathrm{~cm}^{2} \mu \mathrm{g}^{-1}$ (at $880 \mathrm{~nm})$. Assuming that most of light absorption is due to $\mathrm{BC}$ at $880 \mathrm{~nm}$, for the convenience of comparisons with the model simulations, we refer to these measurements as $\mathrm{BC}$. The error in estimating $\mathrm{BC}$ concentration is expected to be less than $10 \%$ (Hansen, 2005; Gadhavi and Jayaraman, 2010 and references therein).

\subsection{Emission inventory data}

We have considered three emission inventories namely ECLIPSE, RETRO and SAFAR-India. The ECLIPSE (Evaluating the CLimate and air quality ImPacts of Short-livEd pollutants) global emission inventory has been developed using the GAINS Model (Greenhouse gas - Air pollution Interactions and Synergies Model; Amann et al., 2011). The sources considered range from wick lamps to thermal power stations, including residential combustion, transport, shipping, large combustion installations, industrial processes, waste and open burning of agricultural residues. This inventory does not include emissions from open biomass burning other than agricultural waste burning. Hence forest fire emissions are included from GFEDv3 (Global Fire Emissions Database; van der Werf et al., 2010). The ECLIPSE emission data set has been developed for the period from 1990 to 2050; the inventory extends to 2010 while the baseline projection until 2050 assumes implementation of existing environmental legislation and draws on the energy projection of the IEA - International Energy Agency's Energy Technology Perspective 2012 (ETP2012) (Klimont et al., 2015a, b). In this work, emission values for the year 2010 from version 5 of the inventory are used. Version 5 was recently released and has about $44 \%$ higher emissions than version $4 \mathrm{a}$ inventory over India, mainly due to the addition of sources which were not previously considered (e.g. wick lamps). The original data set is available at $0.5^{\circ} \times 0.5^{\circ}$ resolution including monthly resolution for several key source sectors; however in this study, the grid resolution has been reduced to $1^{\circ} \times 1^{\circ}$. Emission fluxes from the ECLIPSE + GFED inventory are shown in Fig. 3a. Hereafter, if not specifically mentioned, reference to ECLIPSE inventory implies ECLIPSE + GFED. The total $\mathrm{BC}$ emissions of India in 2010 are estimated at $1233 \mathrm{Gg} \mathrm{yr}^{-1}$ of which $52 \mathrm{Gg} \mathrm{yr}^{-1}$ are from forest fire emissions based on GFED. The major contribution originates from the IndoGangetic Basin (IGB) in the north and in a few pockets on the western coast of India. In contrast, in South and Central India BC emissions are relatively low. Within IGB, emissions are higher in Bihar, West Bengal and Haryana states of India (a)
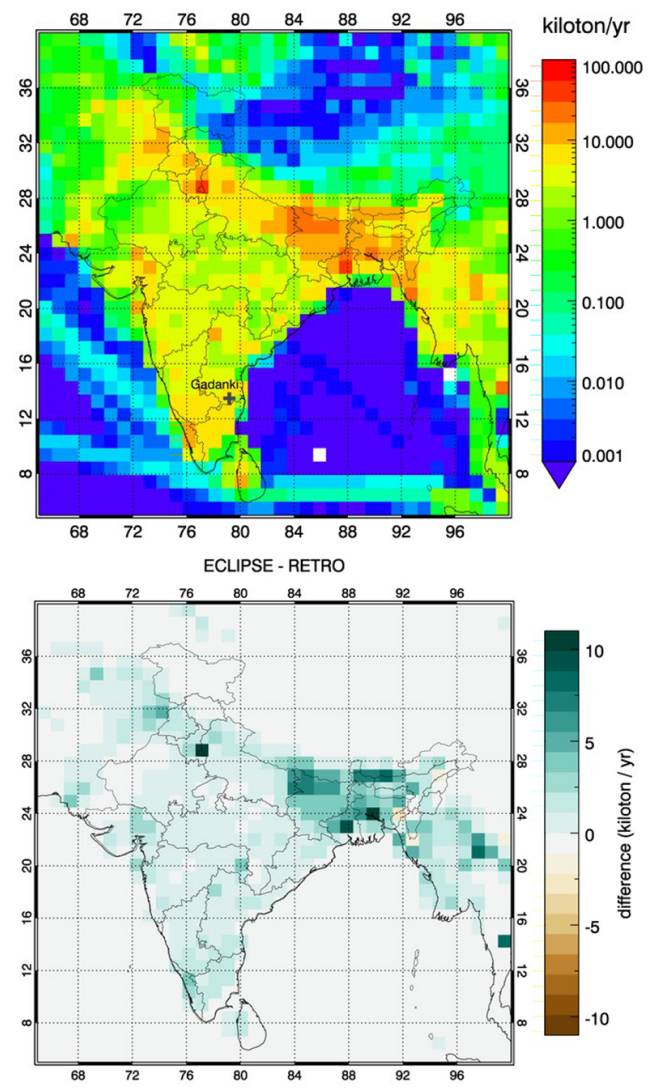

ECLIPSE - SAFAR

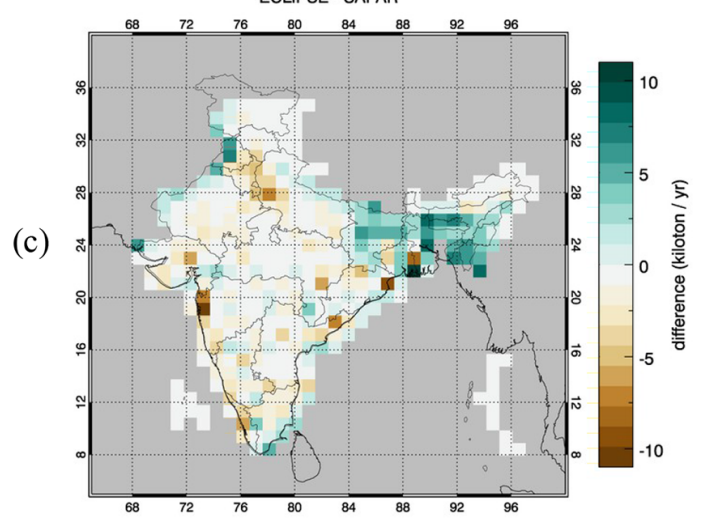

Figure 3. (a) ECLIPSE (ECLIPSE v5 + GFED v3) BC emission inventory over South Asia. (b) Difference between the ECLIPSE and RETRO emissions (ECLIPSE - RETRO). (c) Difference between ECLIPSE and SAFAR India emissions (ECLIPSE - SAFAR). Here and in rest of the paper political borders are shown for cursory region identification and may not be accurate.

and Bangladesh (a map of India with state names is provided in the Supplement).

The RETRO emission inventory is the outcome of the project REanalysis of the TROpospheric (RETRO) chemical composition over the past 40 years. The emission inventory for BC has two parts - one for anthropogenic emissions which includes biofuel burning, industrial combustion and 
agricultural residue burning. $\mathrm{BC}$ emissions from forest fires over India are accounted for separately based on the RegFIRM model (Schultz et al., 2008). Schultz et al. (2008) had to reduce the literature values for carbon emissions per unit area over India to achieve consistency with reported emissions from the subcontinent which highlights inherent problems in the bottom-up inventory approach for emissions from biomass burning. The emission fluxes are monthly averages of $\mathrm{BC}$ in $\mathrm{kg} \mathrm{m}^{-2} \mathrm{~s}^{-1}$ for each grid-box. Annual total BC emissions of India based on this inventory for the year 2010 are $697 \mathrm{Gg} \mathrm{yr}^{-1}$ out of which $31 \mathrm{Gg} \mathrm{yr}^{-1}$ are from forest fires. In Fig. 3b, differences between ECLIPSE and RETRO (ECLIPSE - RETRO) are shown, i.e. RETRO emission fluxes are lower than ECLIPSE emissions in all of South Asia. The difference is particularly high over the Bihar, West Bengal states of India, and Bangladesh and Myanmar.

Finally, we have considered the regional emission inventory SAFAR (System of Air quality Forecasting and Research)-India (Sahu et al., 2008). The SAFAR-India includes only anthropogenic emissions from fossil fuel, fuel wood, dung combustion and agricultural waste burning using district-level statistics on activities, population, farming, etc. In preparation of the inventory, Sahu et al. (2008) have used emission factors for biofuel combustion from Venkataraman et al. (2005), and emission factors for fossil fuel combustion are based on Cooke et al. (1999) for their "under-developedcountries" category. The inventory was updated after publication of Sahu et al. (2008). The latest inventory contains annual emissions for the years 1991, 2001 and 2011 at a spatial resolution of $1^{\circ} \times 1^{\circ}$. In this work, we have used emission values for 2011. Total BC emissions of India based on this inventory are $1119 \mathrm{Gg} \mathrm{yr}^{-1}$. Although ECLIPSE and SAFAR inventory have comparable total emissions for India, their spatial and source distribution are significantly different. In Fig. 3c, spatial allocation differences between ECLIPSE and SAFAR (ECLIPSE - SAFAR) are shown. SAFAR inventory has comparable or marginally higher emissions in central, southern and western parts of India. Regions close to big cities like Mumbai, Delhi, Ahmedabad and Kolkata have significantly higher emissions in SAFAR compared to ECLIPSE. The opposite is true over Bihar, West Bengal and northeastern parts of India, where the ECLIPSE inventory is significantly higher than SAFAR. With respect to source distribution, the key difference is between large combustion plants (power plants and industrial boilers) and the residential sector. SAFAR estimates large BC emissions from power plant boilers while this source is very small in ECLIPSE. This is linked to the emission factors used, i.e. SAFAR uses values from Cooke et al. (1999) who suggested high emission factors for large industrial boilers but Bond et al. (2004) concluded that there is no evidence for so high values. ECLIPSE relies on smaller values as discussed in Bond et al. (2004) and Kupiainen and Klimont (2007). For the residential sector, ECLIPSE includes specific calculation of emissions from diesel generators and wick lamps; particularly the inclusion of the latter source resulted in additional BC emissions leading to higher estimates in version 5 of ECLIPSE.

\subsection{Model description}

We have used the Lagrangian particle dispersion model (LPDM) FLEXPART v9.0 (Stohl et al., 1998, 2005). The LPDM computes the trajectories of a large number of particles (infinitesimally small air parcels). Unlike ordinary air back-trajectory models, FLEXPART includes several processes important for aerosol dispersion and removal like diffusion by turbulence in the boundary layer and aloft, deep convective mixing, dry deposition and wet deposition. The representation of narrow plumes is not possible in Eulerian models whereas in LPDM one can track the particles correctly at subgrid scale. Furthermore, FLEXPART can be run in both forward- and backwardin-time modes. The output of the forward modelling from emission sources are simulated concentration fields, whereas a backward run of the model initialized from a receptor point (typically, a measurement location) provides source-receptor (S-R) relationships or potential emission sensitivity (PES) fields. A detailed description of the FLEXPART-based S-R relationship can be found in Seibert and Frank (2004). It is related to the residence time of particles in output grid cells. The S-R relationship describes the sensitivity of receptor $y$ to source $\boldsymbol{x}$. In the present case, the receptor $\boldsymbol{y}$ is a vector of $24 \mathrm{~h}$ average $\mathrm{BC}$ concentrations at Gadanki for different days, and source $\boldsymbol{x}$ is vector of area-averaged BC emissions in different grid-boxes at different time intervals. In case of FLEXPART based S-R relationship, the S-R relationship is a matrix $\mathbf{M}$ whose elements $m_{i l}$ are defined by $m_{i l}=\frac{y_{l}}{x_{i}}$ (Seibert and Frank, 2004). Once the matrix $\mathbf{M}$ is known for a given source vector (emission inventory), receptor values (BC concentrations at measurement site) can be obtained by a simple matrix-vector multiplication. The backward (also known as retroplume) runs are particularly useful to understand the regional distribution of sources contributing to pollution at the observation site and the corresponding transport pathways and for evaluating emission inventories using point observations.

We have used the NCEP Global Forecast Systems Final GFS-FNL; NCEP (2000); hereinafter referred to as FNL data - meteorological analysis data to drive FLEXPART. GFSFNL data are available at $1^{\circ} \times 1^{\circ}$ spatial resolution and at 6hourly temporal resolution. Vertically, the data are available at 26 pressure levels extending from the surface to $10 \mathrm{hPa}$.

We have used backward runs of FLEXPART to simulate the $\mathrm{BC}$ concentrations at Gadanki to understand the relative merit of various inventories for the comparison of modelled values with observations. Various settings for the model runs are summarized in Table 1. In the backward runs, BC particles were traced backward in time from the receptor site (Gadanki) for 10 days. The simulations were carried out for every day of the years 2009 and 2011. Since the 
Table 1. FLEXPART model set-up for retroplume runs from Gadanki.

\begin{tabular}{ll}
\hline $\begin{array}{l}\text { Input meteorological data } \\
\text { Tracer }\end{array}$ & $\begin{array}{l}\text { NCEP-GFS data at } 1^{\circ} \times 1^{\circ} \text { global } \\
\text { Black carbon aerosol }\end{array}$ \\
\hline Point of origin for retroplume & $\begin{array}{l}\text { Gadanki }\left(13.48^{\circ} \mathrm{N}, 79.18^{\circ} \mathrm{E}, 365 \mathrm{~m} \text { a.s.l. }\right), \\
\text { altitude: } 0-100 \mathrm{~m} .\end{array}$ \\
\hline Output grid & $\begin{array}{l}\text { Horizontal: } 1^{\circ} \times 1^{\circ} \text { global; Vertical: } 0-100, \\
100-3000,3000-5000 \mathrm{~m} \text { a.g.l. }\end{array}$ \\
\hline Mode & Backward runs \\
\hline Number of days backward for each release & 10 days \\
\hline Dry deposition & Enabled for 2009 and 2011 \\
\hline Convection & Enabled for 2009 and 2011 \\
\hline Wet deposition & Enabled only for year 2011 \\
\hline Dry deposition parameters & $\begin{array}{l}\text { Density }(\text { rho })=1400 \mathrm{~kg} \mathrm{~m}{ }^{-3} \\
\text { Mean Diameter }\left(d_{\mathrm{p}}\right)=0.25 \mu \mathrm{m}\end{array}$ \\
& Sigma of log-normal distribution $(\mathrm{dsig})=1.25$ \\
\hline Below-cloud scavenging parameters & $\begin{array}{l}\text { Scavenging coefficient at rainfall rate } \\
1 \text { mm } \mathrm{h}^{-1}(A)=2 \times 10^{-7} \mathrm{~s}-1\end{array}$ \\
& Dependency factor $(B)=0.62$ \\
\hline
\end{tabular}

FNL data do not include precipitation values for the year 2009 , the model particles were subjected to only dry deposition in the year 2009 whereas the particles were subjected to both dry and wet deposition in the year 2011. To calculate dry deposition, the particle density, aerodynamic diameter and standard deviation of a log-normal distribution were assumed to be $1400 \mathrm{~kg} \mathrm{~m}^{-3}, 0.25 \mu \mathrm{m}$ and 1.25 , respectively following Stohl et al. (2013). Below-cloud scavenging is modelled using a wet scavenging coefficient defined as $\lambda=A I^{B}$, where $A$ is the wet scavenging coefficient at precipitation rate $(I)$ equal to $1 \mathrm{~mm} \mathrm{~h}^{-1}$, and $B$ is the factor dependency (McMahon and Denison, 1979). We have set values of $A$ equal to $2 \times 10^{-7} \mathrm{~s}^{-1}$ and $B$ equal to 0.62 following Stohl et al. (2013). The in-cloud scavenging is simulated using a scavenging coefficient defined as $\lambda=\left(1.25 I^{0.64}\right) H^{-1}$, where $H$ is cloud thickness in metres (Hertel et al., 1995). The PES values in the bottom-most layer (so-called footprint layer; $0-100 \mathrm{~m}$ a.g.l.) were multiplied by the emission fluxes to calculate the $\mathrm{BC}$ concentration at the receptor.

\section{Results and discussion}

\subsection{Observations}

Daily mean measured $\mathrm{BC}$ concentrations at Gadanki from April 2008 to October 2012 are shown in Fig. 4. BC concentrations at Gadanki vary strongly with season, with high values during late winter and spring and low values during monsoon months. The daily mean values varied from $6.8 \pm 3.1 \mu \mathrm{g} \mathrm{m}^{-3}$ (February) to $0.3 \pm 0.2 \mu \mathrm{g} \mathrm{m}^{-3}$ (Novem-

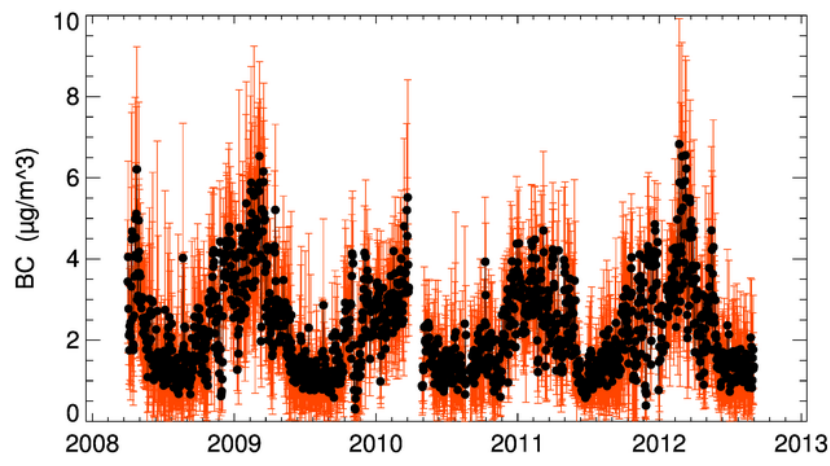

Figure 4. Daily mean BC concentration observed at Gadanki (black dots) and their $\pm 1 \sigma$ standard deviation (orange vertical bars).

ber). Although the data period is not sufficient to do a thorough trend analysis, for the available data, no trend is observed. Also, there are no major differences in seasonal peak and low concentrations from 2008 to 2012. Hence, keeping computational time constraints in mind, the numerical simulations were carried out only for the relatively dry year 2009 and the normally wet year 2011 .

\subsection{Potential emission sensitivity}

The model output is PES values on a three-dimensional grid. Since BC is mainly emitted near surface, we focus here only on the PES of the bottom-most layer from 0-100 $\mathrm{m}$ a.g.l. (the so-called footprint layer) and refer to this simply as PES. PES maps for 5 different days representing different mete- 
(a)

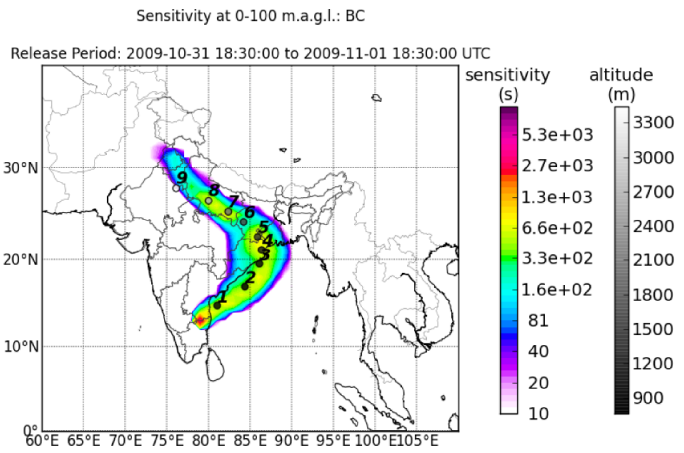

(c)

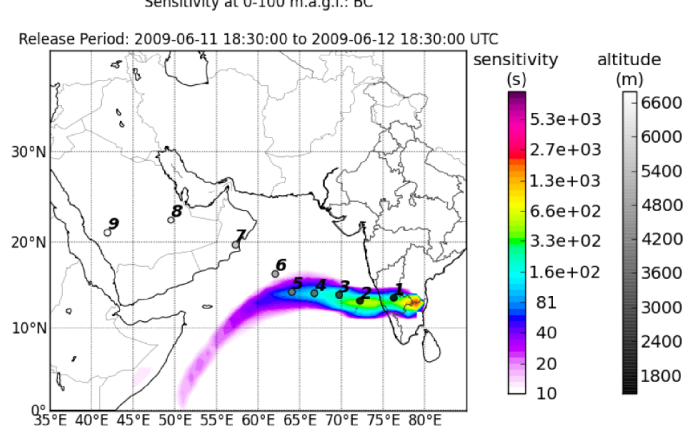

(e)

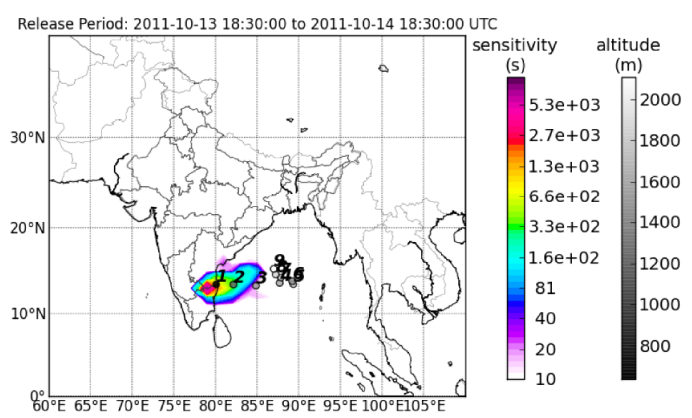

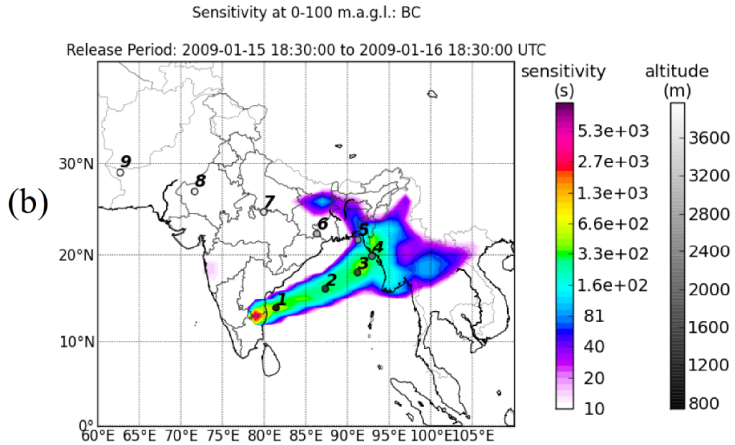
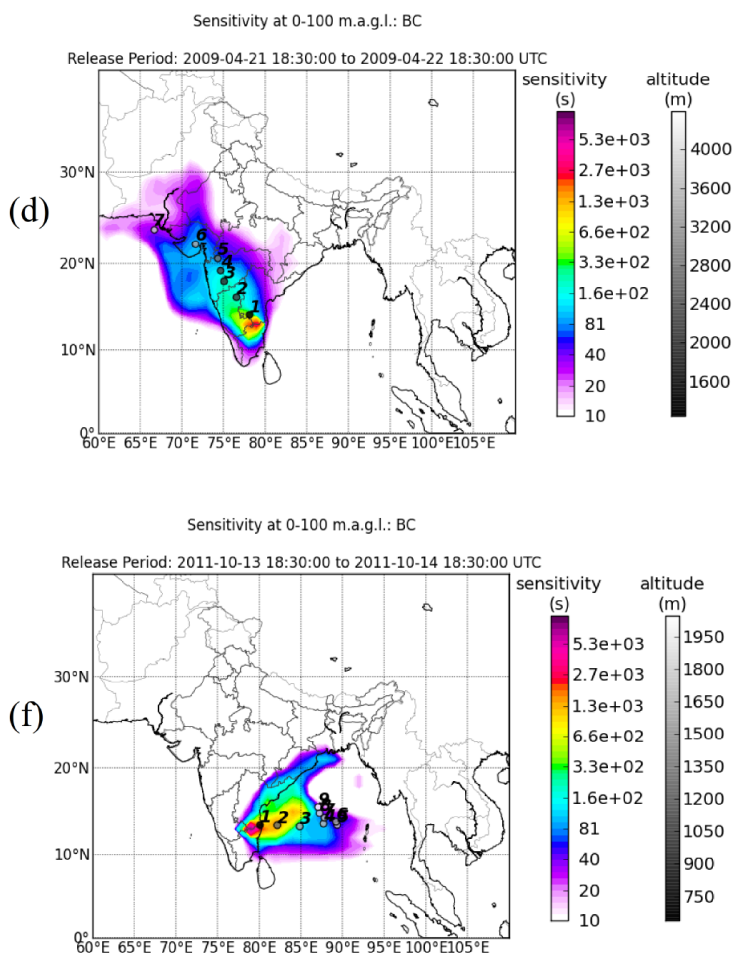

Figure 5. Selected examples of footprint potential emission sensitivity (PES) maps (also known as source-receptor relationships) using 10 days of backward runs (retroplumes) of FLEXPART from Gadanki. Panels (e) and (f) are PES maps of 14 October 2011 local time with and without wet deposition respectively. See Supplement for the PES maps for other days.

orological situations are shown in Fig. 5a-f. PES maps for all the days during 2009 are provided in the Supplement. PES values are represented in a logarithmic colour scale defined at the side of the figure panels. The median height of the retroplume in daily intervals is shown using grey-shaded dots. Depending on the season, Gadanki receives air coming from different regions. Generally, during winter air parcels are either from the Indo-Gangetic Basin (northern India) or Central Bay of Bengal (e.g. Fig. 5a and b). During summer or the southwest monsoon period the air comes from the northern Indian Ocean and Arabian Sea (e.g. Fig. 5c). During the transition period, the air travels over western and central India before reaching Gadanki (e.g. Fig. 5d). It is rare that significant PES values occur over Southeast Asian coun- tries or China, though in a few instances trajectories came from Myanmar, Southeast Asian countries and South China (e.g. Fig. 5b). The advantage of a dispersion model vis-à-vis a simple air trajectory model can be seen in Fig. 5c. The median trajectory shown with grey dots is found to pass over the Arabian Peninsula, though surface PES values are not significant over the Arabian Peninsula, but are substantial over the northern Indian Ocean. In such circumstances, simple air back-trajectory analysis may ascribe observed concentration to emissions over Arabia whereas in reality it is not being influenced by surface emissions over that region. To demonstrate the effect of wet deposition on PES, PES maps for 14 October 2011 are shown with and without wet deposition in Fig. 5e and f respectively. The week preceding 14 October 
2011 had large rainfall over southern India and the Bay of Bengal. Precipitation maps for 6 days from TRMM satellite are provided in the Supplement. Wet deposition is generally the most important removal process for aerosol and its effect on PES can be seen by the reduction of the high PES area especially over the ocean. However, the highest PES values over India close to the observation site remain almost unaffected by precipitation. Simulated BC concentrations for this case with and without precipitation are 1.0 and $1.4 \mu \mathrm{g} \mathrm{m}^{-3}$, respectively.

\subsection{Modelled BC concentrations}

BC concentrations are determined by multiplying the footprint PES values with emission fluxes from the various inventories for every grid point and then integrating over the whole globe. The method implies that BC emissions are uniformly distributed in a grid cell of height $100 \mathrm{~m}$ (height of footprint PES layer). For a surface source, the footprint PES layer should be as small as possible. However, a very shallow footprint layer is not ideal from statistical point of view, as the PES is calculated based on the mass (and, thus, approximately the number) of particles in the footprint layer. With a very shallow height (say, $10 \mathrm{~m}$ ), one would need to release 10 times more particles (number of trajectories) than with a $100 \mathrm{~m}$ height of the footprint layer to arrive at the same statistical error for the footprint PES, whereas increasing the height of the PES layer will not introduce significant error as long as the boundary layer height is higher than the footprint PES layer. BC concentrations are calculated with the three emission inventories ECLIPSE, RETRO and SAFAR-India. The SAFAR-India emission inventory is available only for the Indian region, hence inventory values outside India are set to zero. In the case of the ECLIPSE inventory, emissions outside India including shipping are found to contribute on average $6 \%$ of the total modelled $\mathrm{BC}$ concentrations over Gadanki. There were only 36 days in the year 2009 that had more than $15 \%$ of the BC originating from emissions outside India. Note that for the year 2009, wet deposition was not simulated. In the case of 2011 , for which wet deposition was simulated, emissions outside India contributed $5 \%$ on average and there were only 24 days when their contribution was more than $15 \%$. In Fig. 6, seasonal and annual averages of source contribution maps are shown. During winter the emissions from IGB region (North India) dominate the BC concentrations at Gadanki, whereas during spring, emissions from southern India dominate. During summer, the source region is very small resulting in low concentration of $\mathrm{BC}$ as shown later. Autumn is a transition period from southwest monsoon to northeast monsoon and hence $\mathrm{BC}$ concentrations at Gadanki are due to both northern and southern India emissions. On average, India north of $18^{\circ} \mathrm{N}$ latitude contributes $43 \%$ of simulated $\mathrm{BC}$ mass and the part north of $22^{\circ} \mathrm{N}$ latitude contributes $33 \%$ at Gadanki. The contribution increases to 67 and $57 \%$ during winter from the two regions, respectively.

A comparison of observed and model-estimated BC concentration for the year 2009 is shown in Fig. 7a. There are no big differences between the three emission inventories. $\mathrm{BC}$ estimates based on RETRO are a little lower than for the other inventories, as expected, since total BC emissions of India $\left(697 \mathrm{Gg} \mathrm{yr}^{-1}\right.$ ) in RETRO are significantly lower than in the other two inventories. Overall, the seasonal pattern is well reproduced in the model runs. Several submonthly-scale variations of observed $\mathrm{BC}$ concentrations are also well reproduced by the model, confirming its ability to simulate the influence of short-term changes in the meteorological conditions. During autumn and winter, the observed values are reproduced by the model within around $30 \%$ but the model underestimates the observed BC concentrations during spring and summer quite substantially. In Table 2, values of annual and seasonal averages, observation to model ratio, mean biases, root mean square differences (RMSD) and correlation coefficients $(R)$ between observation and model for different inventories are shown. Overall, SAFAR has the smallest bias $\left(0.8 \mu \mathrm{g} \mathrm{m}^{-3}\right.$ and least RMSD $\left(1.4 \mu \mathrm{g} \mathrm{m}^{-3}\right.$ in 2009 and $1.1 \mu \mathrm{g} \mathrm{m}^{-3}$ in 2011) with comparable values for ECLIPSE. The bias is small during autumn in general. In fact, with the SAFAR inventory, the model overestimates the observed concentrations during autumn of 2009 by a small amount $\left(0.104 \mu \mathrm{g} \mathrm{m}^{-3}\right)$. The largest bias and RMSD are found during spring. Note that seasonal variations in model values are purely due to meteorology and transport as emission fluxes are constant within a month in the ECLIPSE and RETRO inventories and throughout the year for SAFAR inventory. Although the SAFAR inventory has seasonally fixed emission fluxes, the model's performance using the SAFAR inventory is not very different compared to using the ECLIPSE inventory. This is because BC emissions in ECLIPSE inventory has very small seasonal variation. Monthly $\mathrm{BC}$ emissions of India in ECLIPSE (excluding GFED) inventory vary from 93.7 Gg in September to a maximum 104.2 Gg in July mainly due to seasonal variation of agricultural waste burning, which varies from 1.2 to $10.5 \mathrm{Gg}$. Together with GFED, there is less than $4.1 \%$ monthly variation of total BC emissions in a year in India.

As mentioned before, simulations for the year 2009 were carried out without including the wet deposition process. When including wet deposition for the year 2009, the underestimation may even be larger than that reported here. However, in Fig. 7b and c, we show a comparison for the year 2011 without and with wet deposition, respectively. It can be seen that the wet deposition has very little effect and hardly produces perceptible differences between Fig. 7b and c. Overall, wet deposition reduces modelled BC values by only $8 \%$ when using the ECLIPSE inventory. Seasonally, the wet deposition is found to be reducing modelled $\mathrm{BC}$ values by $5 \%$ in winter, $6 \%$ in spring, $14 \%$ in summer and $15 \%$ in autumn. Such seasonal influence is expected as 
(a)

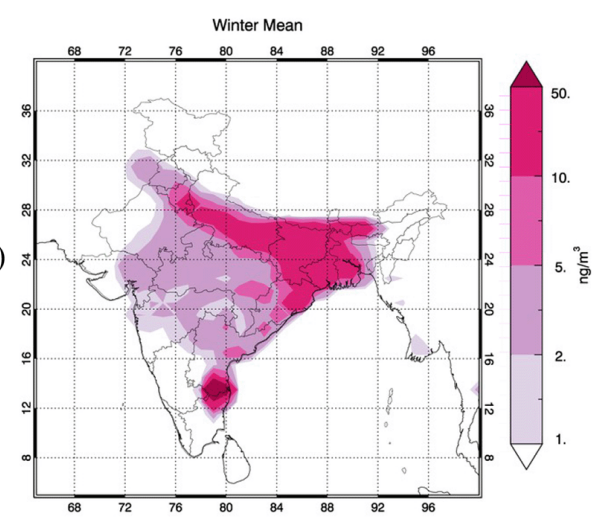

(c)

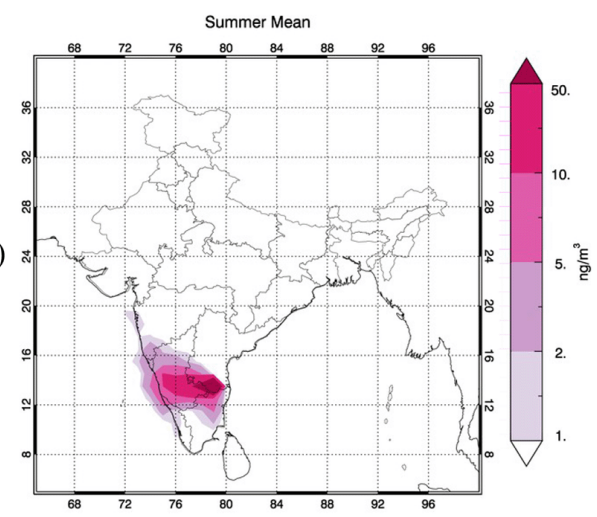

(e)

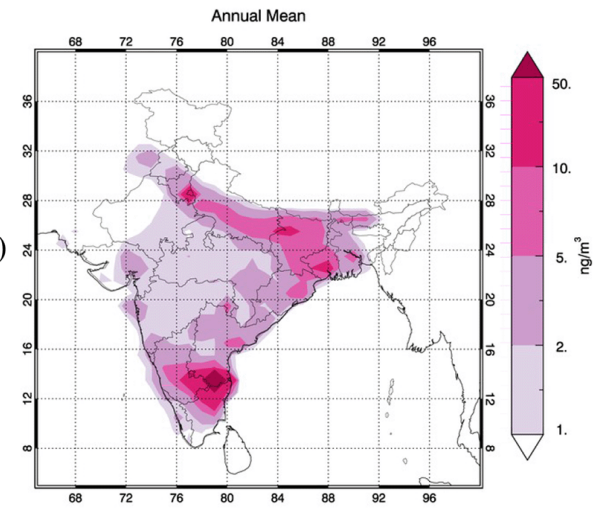

(b)

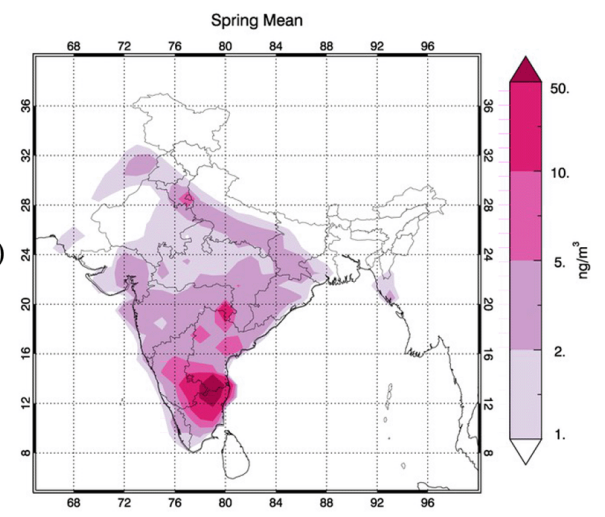

(d)

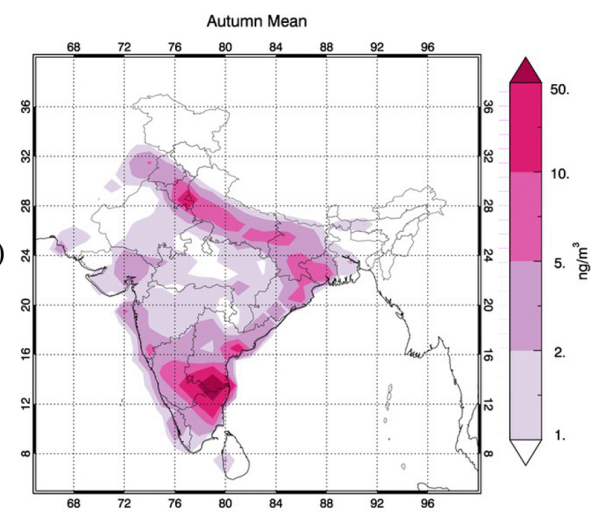

Figure 6. BC source contribution (per $1^{\circ} \times 1^{\circ}$ grid cell) maps based on FLEXPART retroplume calculations and the ECLIPSE inventory. Values are for seasonal averages, i.e. (a) winter, (b) spring, (c) summer, (d) autumn and (e) annual average for year 2009.

the maximum rain over Gadanki is received during summer and autumn (see Fig. 1). There were about 76 days in the year 2011 when wet deposition reduced the $\mathrm{BC}$ concentrations by more than $15 \%$. In summary, wet deposition is not a major factor that causes underestimation of model BC values over Gadanki. This is a result of the relatively short rainy season over major parts of India and the short transport times during the rainy season for a major fraction of the $\mathrm{BC}$ between its emission and the arrival at Gadanki, rendering precipitation scavenging an ineffective process for this particular site. This result is site specific and does not imply that wet deposition is globally of minor importance. On the contrary, it is the main removal mechanism for $\mathrm{BC}$ in the model.

In Fig. 8, the average age spectra (measuring the time between $\mathrm{BC}$ emission and $\mathrm{BC}$ arrival at Gadanki) of modelled $\mathrm{BC}$ values estimated using the ECLIPSE inventory are shown for the full year as well as for the four seasons. One can see that on average about 30 to $40 \%$ of BC mass is of age 4 days or more. During winter this value increases to $65 \%$. In other words, a large fraction of $\mathrm{BC}$ mass during winter is due to long-range transport of $\mathrm{BC}$ particles from northern India. If the dry deposition process is the reason for underestimation then one may expect larger model biases in winter. Instead, 
Table 2. Average, ratio, bias, RMSD and correlation coefficient between modelled and observed BC concentrations when using different inventories for the years 2009 and 2011.

\begin{tabular}{|c|c|c|c|c|c|c|c|c|c|}
\hline & & \multicolumn{4}{|c|}{$2009^{*}$} & \multicolumn{3}{|c|}{$2011^{*}$} & \multirow[b]{2}{*}{ RETRO } \\
\hline & & Obs. & SAFAR & ECLIPSE & RETRO & Obs. & SAFAR & ECLIPSE & \\
\hline \multirow{5}{*}{$\begin{array}{l}\text { Mean } \\
\left(\mu \mathrm{g} \mathrm{m}^{-3}\right)\end{array}$} & All & 2.308 & 1.494 & 1.378 & 0.936 & 2.279 & 1.483 & 1.454 & 1.05 \\
\hline & Winter & 3.405 & 2.179 & 2.182 & 1.643 & 3.213 & 2.367 & 2.624 & 2.103 \\
\hline & Spring & 2.998 & 1.452 & 1.366 & 0.835 & 2.591 & 1.345 & 1.242 & 0.800 \\
\hline & Summer & 1.181 & 0.595 & 0.496 & 0.232 & 1.234 & 0.595 & 0.467 & 0.229 \\
\hline & Autumn & 1.700 & 1.805 & 1.525 & 1.087 & 2.110 & 1.653 & 1.518 & 1.118 \\
\hline \multirow{5}{*}{$\begin{array}{l}\text { Ratio } \\
\text { (Obs/Model) }\end{array}$} & All & 1 & 1.545 & 1.675 & 2.465 & 1 & 1.537 & 1.568 & 2.162 \\
\hline & Winter & 1 & 1.563 & 1.561 & 2.072 & 1 & 1.357 & 1.225 & 1.528 \\
\hline & Spring & 1 & 2.065 & 2.196 & 3.593 & 1 & 1.926 & 2.086 & 3.239 \\
\hline & Summer & 1 & 1.986 & 2.38 & 5.098 & 1 & 2.075 & 2.641 & 5.396 \\
\hline & Autumn & 1 & 0.942 & 1.115 & 1.564 & 1 & 1.277 & 1.390 & 1.888 \\
\hline \multirow{5}{*}{$\begin{array}{l}\text { Bias } \\
\left(\mu g \mathrm{~m}^{-3}\right) \\
\text { (Model-Obs) }\end{array}$} & All & - & -0.814 & -0.930 & -1.372 & - & -0.796 & -0.825 & -1.225 \\
\hline & Winter & - & -1.226 & -1.224 & -1.762 & - & -0.846 & -0.589 & -1.110 \\
\hline & Spring & - & -1.547 & -1.633 & -2.164 & - & -1.246 & -1.349 & -1.791 \\
\hline & Summer & - & -0.586 & -0.684 & -0.949 & - & -0.639 & -0.767 & -1.006 \\
\hline & Autumn & - & 0.104 & -0.175 & -0.613 & - & -0.458 & -0.592 & -0.992 \\
\hline \multirow{5}{*}{$\begin{array}{l}\text { RMSD } \\
\left(\mu \mathrm{g} \mathrm{m}^{-3}\right)\end{array}$} & All & - & 1.401 & 1.419 & 1.726 & - & 1.082 & 1.254 & 1.448 \\
\hline & Winter & - & 1.637 & 1.691 & 2.006 & - & 1.216 & 1.536 & 1.498 \\
\hline & Spring & - & 2.017 & 2.031 & 2.457 & - & 1.426 & 1.495 & 1.917 \\
\hline & Summer & - & 0.669 & 0.752 & 0.992 & - & 0.709 & 0.826 & 1.053 \\
\hline & Autumn & - & 0.809 & 0.710 & 0.936 & - & 0.821 & 1.015 & 1.163 \\
\hline \multirow{5}{*}{$\begin{array}{l}\text { Correlation } \\
\text { Coefficient } \\
(R)\end{array}$} & All & - & 0.483 & 0.542 & 0.543 & - & 0.726 & 0.661 & 0.690 \\
\hline & Winter & - & 0.138 & 0.036 & 0.021 & - & 0.473 & 0.334 & 0.375 \\
\hline & Spring & - & 0.063 & 0.249 & 0.422 & - & 0.501 & 0.605 & 0.560 \\
\hline & Summer & - & 0.483 & 0.439 & 0.431 & - & 0.587 & 0.545 & 0.561 \\
\hline & Autumn & - & 0.616 & 0.646 & 0.547 & - & 0.738 & 0.709 & 0.729 \\
\hline
\end{tabular}

Winter: December to February; spring: March to May; summer: June to August; autumn: September to November. RMSD: root mean square deviation * Note: calculations for 2011 are with wet deposition; calculations for 2009 are without wet deposition. ECLIPSE inventory includes ECLIPSE v5, GFED v3 and shipping emissions.

during winter, the comparison between model and observations is better. Hence, dry deposition may also not be an important factor for causing the underestimation.

The differences between observation and model are in fact correlated to biomass burning activity (see Fig. 2; also see seasonal maps of fire hotspots overlaid on PES in the Supplement). Since, SAFAR-India inventory considers only anthropogenic emissions and do not include forest fire emissions, such underestimation during spring (open biomass burning season) is expected for it. The RETRO inventory has BC emissions from forest fires and in the case of ECLIPSE inventory, forest fire emissions are included from GFEDv3. In spite of this, ECLIPSE and RETRO inventories have similar underestimation like SAFAR-India during spring. The modelled BC values using ECLIPSE and RETRO are about a factor 2.1 and 3.5 lower than the observed $\mathrm{BC}$ concentration $\left(2.8 \mu \mathrm{g} \mathrm{m}^{-3}\right)$ respectively. The variation of monthly BC emissions from forest fires in GFED and RETRO are similar to the monthly variations of FRP shown in Fig. 2 with max- imum emissions of $45 \mathrm{Gg}$ in the case of GFED and $24 \mathrm{Gg}$ in the case of RETRO during March. However, BC emissions from forest fires over India in GFED and RETRO are lower than anthropogenic emissions by a factor of 23 annually and by a factor of 2.2 to 2.8 during March (peak biomass burning season). The year 2009 was a drought year and had a higher number of forest fire events. This is reflected in higher observed $\mathrm{BC}$ concentrations during spring of 2009 compared to the spring of 2011 (see Figs. 4 and 7). In spite of the low BC values during spring of 2011 (being a normal year from drought or forest fire events perspective), all the three inventories still significantly underestimate the observations (see Table 2). The fraction of BC particles of age less than 4 days is $61 \%$ in the year 2009 and $70 \%$ in the year 2011 (see Fig. 8). In other words, freshly emitted particles over southern India form a major part of the total BC load during summer and spring (see Fig. 6). Hence, our analysis suggests that underestimation is due to underestimation of emissions over southern India; however, it is 
(a)

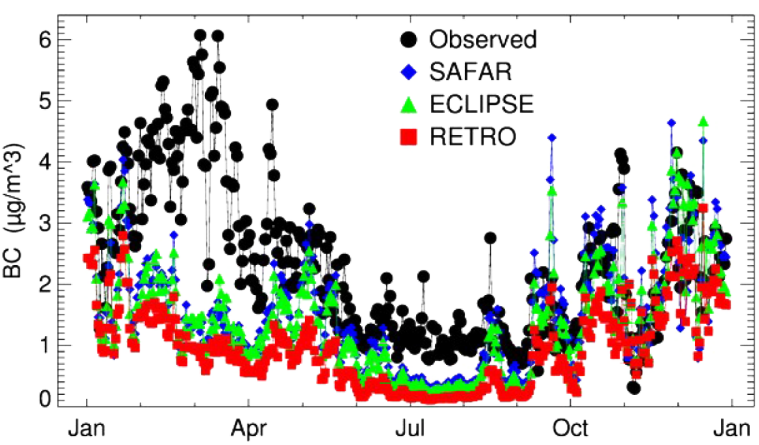

(b)

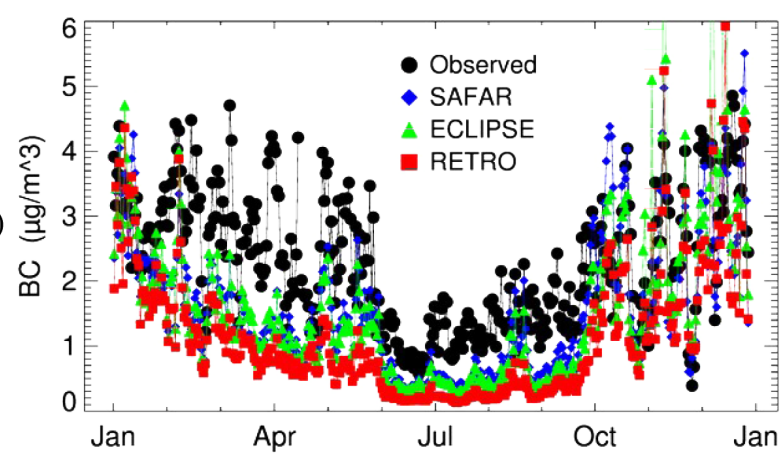

(c)

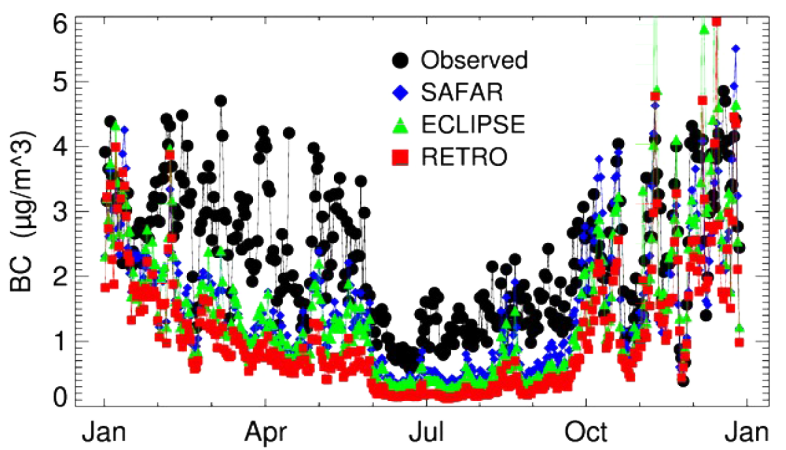

Figure 7. Comparison of observed and model estimated BC concentration: (a) 2009 without wet deposition, (b) 2011 without wet deposition, (c) 2011 with wet deposition.

difficult to pinpoint sectors that are being underestimated for $\mathrm{BC}$ emissions. Contextual information such as underestimation being correlated to FRP suggests that $\mathrm{BC}$ emissions from open biomass burning may be the main sector responsible for underestimation of BC concentration at Gadanki. Gustafsson et al. (2009) and Sheesley et al. (2012) apportioned carbonaceous aerosols using radiocarbon technique over two locations influenced by air masses from India and found biomass burning contributing to the extent of $70 \%$ of total mass of carbonaceous aerosols. Pavuluri et al. (2011) studied the correlation of $\mathrm{BC}$ with levoglucosan and nonsea-salt $\mathrm{K}^{+}$at Chennai (a major city in southern India) and found that biomass burning is the major source of them during winter and summer. Lelieveld et al. (2001) estimated the contribution of biomass burning in $\mathrm{CO}$ in the range of 60 to
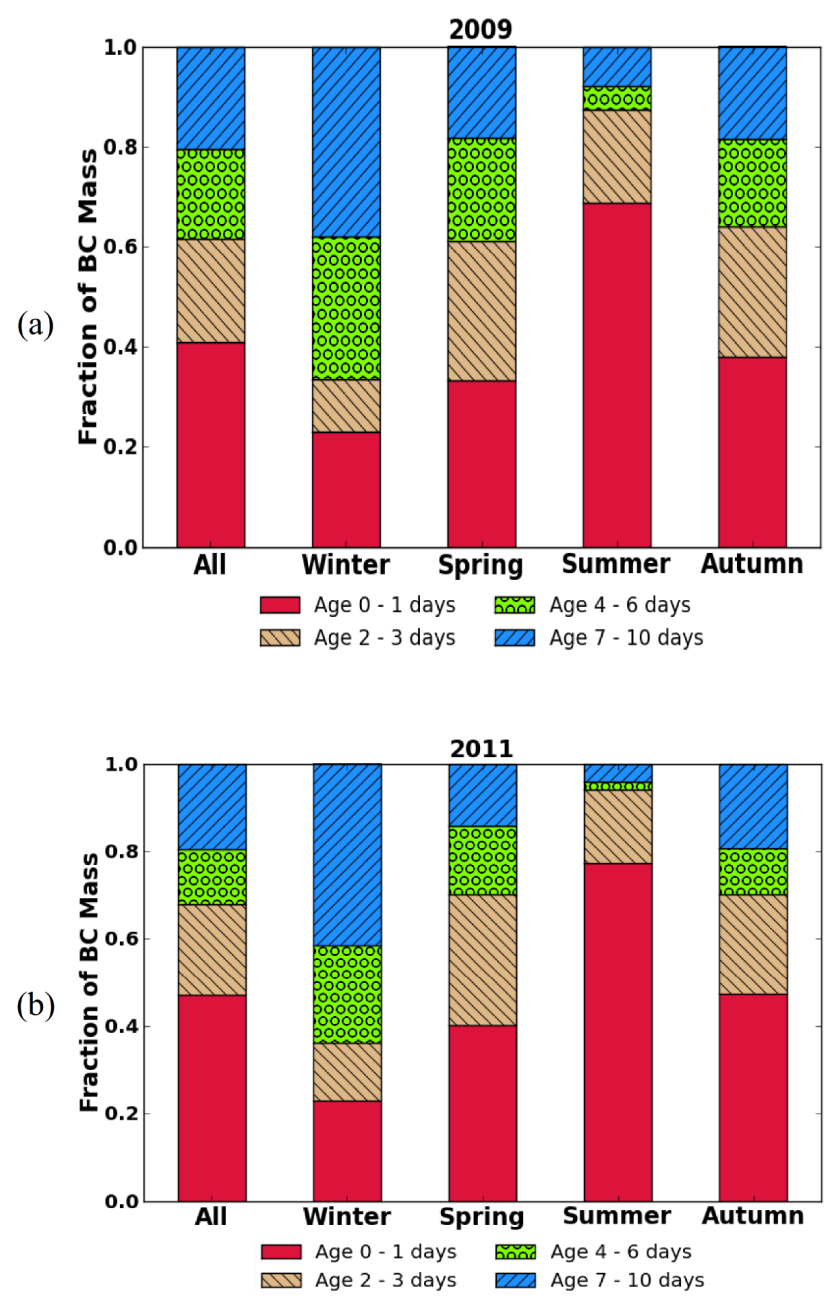

Figure 8. Fraction of simulated $\mathrm{BC}$ mass at Gadanki with particles of different age for year (a) 2009 and (b) 2011. Age 0-1 days represents contribution from day 1 for the backward simulation. Age 2-3 days represents day 2 and day 3 contribution, Age 4-6 days represents day 4 to day 6 and Age 7-10 represents day 7 to day 10 . Note that 2009 simulations are without wet deposition whereas 2011 simulations are with wet deposition.

$90 \%$ using correlation with $\mathrm{CH}_{3} \mathrm{CN}$ and radiocarbon technique during Indian Ocean Experiment (INDOEX). However, underestimation of open biomass burning as a source cannot explain fully the underestimation of $\mathrm{BC}$ concentration by the model during summer when biomass burning activity is low. A possibility exists that the aethalometer may overestimate $\mathrm{BC}$ concentration during summer. The aethalometer relates absorption by particles on filter paper to $\mathrm{BC}$ mass. During summer when wind speeds and direction are conducive for dust aerosol, atmosphere may have a high level of dust amount. Dust is a weakly absorbing type of aerosol. The mass absorption cross-section of dust is 9 times lower than the BC mass absorption cross-section (Zhang et al., 2008). However, during summer, when $\mathrm{BC}$ concentrations are low, 
absorption by dust particles can be a significant part of total absorption by the particles on the filter paper and may be wrongly attributed to BC mass. In the absence of chemical analysis, we rely on the spectral signature of the absorption coefficient for qualitative information on aerosol type. Zhang et al. (2008) have found an inverse wavelength $\left(\lambda^{-1}\right)$ dependence of the absorption coefficient for $\mathrm{BC}$ particles and no significant wavelength dependence for dust particles observed in China. The exponent of wavelength (in power-law form of the relation between absorption coefficient and wavelength) is reported as between -1.5 and -3 for $\mathrm{BC}$ particles emitted in biomass burning (Bergstrom et al., 2004, 2007; Kirchstetter et al., 2004; Clarke et al., 2007). The spectral characteristics of dust particles vary from place to place and the wavelength exponent is reported as between -2 and -3 for some of the places in Asia and Africa (Bergstrom et al., 2004, 2007; Fialho et al., 2005). Monthly median values of wavelength exponent based on seven wavelengths of aethalometer at Gadanki are found to vary between -0.98 to -1.18 for year 2009 (Figure absorption_alpha_2009.png in the Supplement). However, the variability as indicated by interquartile range is found to have increased significantly during summer, indicative of an increase in heterogeneity of absorbing aerosol types during summer. Hence, dust aerosols may be a factor but it may not account for all the difference between model and observation during summer.

This suggests that not only biomass burning but also other anthropogenic emissions in South India are underestimated. BC emission ratios vary within a country due to different stages of economic development (power plant and auto-mobile technology, environmental regulations enforcement). Changes, particularly environmental regulations and their implementation, can be highly region/place specific. Moreover, the changes can be non-linear in time. southern states in India are comparatively more industrialized than northern states but have lower population growth. If emission ratios are generalized for whole country or linear growth is assumed based on population, it may introduce errors in emission inventory. In addition, small-scale anthropogenic biomass burning can be significant. While satellite-based fire detection is low during summer, radiocarbon-based and levoglucosan-based BC apportionment suggest significant contribution of $\mathrm{BC}$ from biomass burning during summer (Pavuluri et al., 2011; Sheesley et al., 2012). Indoor biomass burning and small-scale agricultural waste burning will go unnoticed in satellite data due to increased cloudiness during summer. When overall BC concentrations are low, underestimation of these sources may cause significant fractional error in the estimated BC concentrations.

Overall, although underestimation of anthropogenic emissions cannot be ruled out, underestimation of $\mathrm{BC}$ concentration at Gadanki is likely related to underestimation of $\mathrm{BC}$ emission fluxes from forest fires and/or agricultural waste burning over southern India, particularly during spring.

\section{Case studies}

Since emission inventories for the years 2009 and 2011 are kept the same, the difference in model values between these two years is purely due to meteorology. In the rest of the paper, we focus on the year 2009. As noted in the previous section, the model underestimates $\mathrm{BC}$ values during spring and summer. The underestimation of $\mathrm{BC}$ concentrations may be related to underestimation of biomass burning activity during the dry season and subregionally incorrect anthropogenic emission fluxes. Here we discuss a few cases from the year 2009 which provide insight into these aspects.

In Fig. 9, a comparison of modelled and observed BC concentration over Gadanki for the year 2009 is shown. It is similar to Fig. 7a, but zoomed-in for three different periods. Note the sudden decrease in BC concentration for both observation and model on 8 January in Fig. 9a. From 1 to 6 January, high PES extended along the east coast of India and IndoGangetic Basin (IGB) region. However, from 7 January onward the PES region started shifting away from the coastline towards the central Bay of Bengal (BoB). On 8 January, the high PES region was a narrow region stretching eastward up to Andaman Nicobar Island and then turning northward up to Bangladesh. Oceanic regions do not have many BC sources except for exhaust from ships plying in the region. Simultaneous decrease in observed and modelled values in this case is indicative of the fact that a large part of the BC observed over Gadanki is transported rather than of local origin. Notice that in the model, $\mathrm{BC}$ variations are mainly due to changes in air mass transport (and precipitation in the case of year 2011) because the emissions are kept constant for at least 1 month. From 9 January onward, the high PES region moves again closer to the east coast of India but does not penetrate deep inland. However, on 13 January, the high PES region is found to be covering the whole of Bangladesh, and Bihar and West Bengal states of India. On 13 January, a BC peak is found in observations and in the model. Again on 16 January, the high PES region moved toward central BoB and away from the east coast of India (see Fig. 5b). However, unlike the 8 January event, in this case the high PES region is a little further north and east in the BoB and touches southern Myanmar. The decrease in the case of models is higher than was found for 8 January but the decrease in observed BC concentration is not as big as for 8 January. This is possible if emission fluxes over the high PES region are underestimated.

From 16 January onward, the PES region moves toward India systematically and deep inland over the IGB region. On 21 January the PES region covers the whole of West Bengal, Bihar and Delhi, and large parts of Orissa, Uttarpradesh and Haryana states of India in and around IGB. On 21 January both model and observation have high concentration close to $4 \mu \mathrm{g}$ and there are relatively small differences between model and observations. This is indicative that the inventory values are realistic for this region, although perhaps still underestimate true emissions. 
(a)

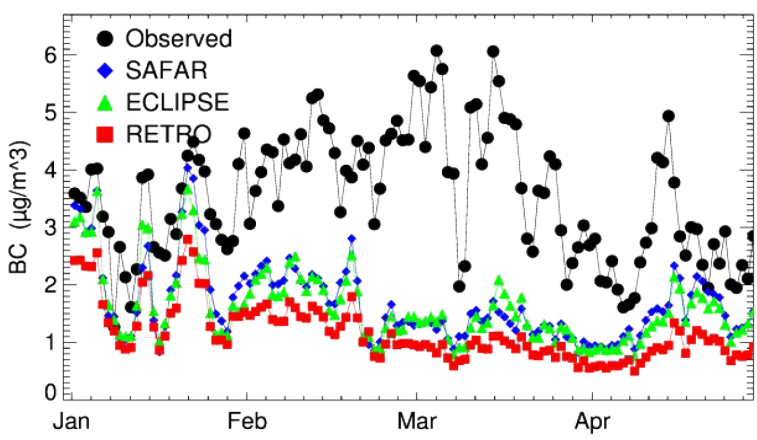

(b)

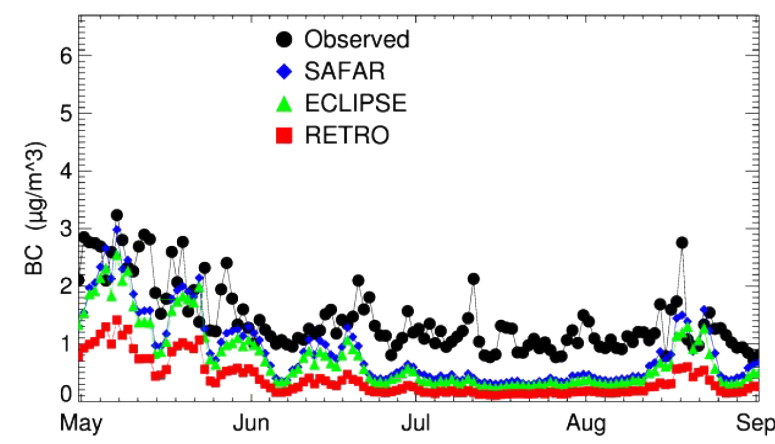

(c)

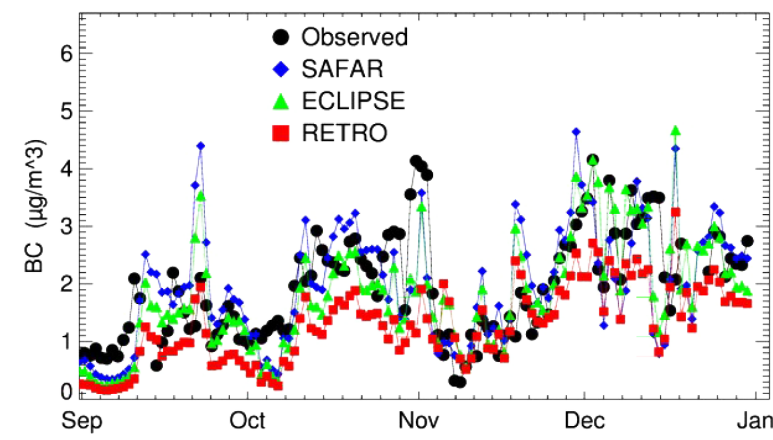

Figure 9. As Fig. 7a, but zoomed in for period (a) January to April, (b) May to August and (c) September to December.

During February and to the middle of March, observed BC concentrations are increasing whereas model values are systematically decreasing. During this period the high PES region has moved away from India towards the BoB, whereas the PES region in the immediate vicinity of Gadanki has moved southward over Tamil Nadu state of India. The large divergence between observation and model is an indication that the inventoried emission fluxes are significantly underestimated over southern India. This is also a period of high biomass burning activity in the region of the high PES (see Fig. 2). Hence, underestimation may be related specifically to underestimation of open biomass burning in southern India.

From 22 April, the high PES region moves to the west of the observation site, over Karnataka state of India and the Arabian Sea (see Fig. 5d), occasionally moving south of the observation site over entire Tamil Nadu. During later part of May, and June and July months, the high PES region is mostly over the Arabian Sea with a very small region over land due to strong winds (see Fig. 5c). Both model and observations have low values during this period. However, the model systematically underestimates the observations by a factor of 2 to 3 (see Fig. 9b).

From 5 September onward the PES region covers Andhra Pradesh, Madhya Pradesh and Gujarat states of India. On 22 September, the model significantly overestimates the observation and for some days it remains higher than observations (see Fig. 9c). The high PES region during this period lay over Andhra Pradesh and Tamil Nadu border and over southern Karnataka. From 16 October onwards the PES pattern moves entirely north of the observation site. At the beginning the pattern covers central and western India, but on 1 November the PES pattern is similar to that found during January-February and extends all the way up to the northwest border of India covering the entire Indo-Gangetic region (see Fig. 5a). On this day, the concentration is the highest in model with similar values in observations. During September-December, differences between observation and model estimates are small.

Summarizing the above description, observed and modelled BC values are high when winds are from northern and western India, with relatively small differences between model and observations, indicative of relatively small errors in the emission inventories over this region. When winds are from South or South Central India, the observed values are high but the model values are substantially lower. Coincidentally, this is also the period of high biomass burning activity over southern India. The differences between the model and observation thus suggest that open biomass burning emissions over southern India have been underestimated in all the three inventories.

\section{Conclusions}

Several field studies over India and in adjoining oceans have found high amount of absorbing aerosols. However, models are found to underpredict the observed high concentrations of absorbing aerosols. Using the Lagrangian particle dispersion model FLEXPART and three emission inventories, we compared the simulated $\mathrm{BC}$ concentrations with $\mathrm{BC}$ measurements at a rural site in southern India. As for the other models, FLEXPART underestimates the observed BC concentrations. We found that 93 to $95 \%$ of the model BC concentration is the result of emissions from India. Northern India is a major source of anthropogenic BC particles, but southern India also has significant $\mathrm{BC}$ emissions. This study identifies a potentially significant underestimate of emissions in southern India, which is reflected in a large difference in the observed and modelled BC values in Gadanki during spring when the winds are predominantly from the south. We suggest that the key source for which the emission fluxes may be 
underestimated is open biomass burning. This is not to rule out the possibility that anthropogenic emissions may also be underestimated.

In the three emission inventories that we evaluated, the ECLIPSE inventory has the highest emissions $\left(1.2 \mathrm{Tg} \mathrm{yr}^{-1}\right)$, with similar emissions in the SAFAR-India inventory $\left(1.1 \mathrm{Tg} \mathrm{yr}^{-1}\right)$. This is also reflected in the comparison between the modelled and observed $\mathrm{BC}$ concentration over Gadanki. Modelled BC values based on ECLIPSE and SAFAR-India are higher than the values based on the RETRO inventory. However, they are not high enough to resolve underestimation in most of the seasons. The overall ratio of observation to model is found to be 1.5 for the SAFAR inventory, 1.7 for ECLIPSE inventory and 2.4 for RETRO inventory. Although the ECLIPSE inventory has the highest emissions over India, it is the SAFAR-India inventory that has the lowest ratio because of differences in spatial distribution in emission fluxes. The SAFAR-India inventory has higher emission fluxes over southern India compared to ECLIPSE.

\section{The Supplement related to this article is available online at doi:10.5194/acp-15-1447-2015-supplement.}

Acknowledgements. The authors acknowledge the developers of the FLEXPART model and related software for visualization and for providing the source code, which was obtained from http://flexpart.eu/. The authors also acknowledge the National Center for Environmental Prediction/National Weather Service/NOAA/US Department of Commerce (2000) for providing GFS-FNL analysis data. The authors acknowledge the developers of BC emission inventories, namely (1) the SAFAR-India inventory made available through Emissions of atmospheric Compounds \& Compilation of Ancillary Data (ECCAD) - the GEIA database project from http://eccad.sedoo.fr/, (2) ECLIPSE (Evaluating the Climate and Air Quality Impacts of ShortLived Pollutants; Project no. 282688) made available from http://eclipse.nilu.no/ and (3) RETRO (REanalysis of the TROpospheric chemical composition over the past 40 years) made available from http://retro.enes.org/. The authors acknowledge the use of FIRMS data from the LANCE (the Land Atmosphere Near-real time Capability for EOS) system operated by ESDIS (the NASA/GSFC/Earth Science Data and Information System) with funding provided by NASA/HQ. The authors acknowledge the use of rainfall estimates obtained from the TRMM satellite through the GIOVANNI online data system, developed and maintained by the NASA GES DISC to provide rainfall maps in the Supplement. The authors acknowledge T. N. Rao and his team members for providing weather station data. K. Renuka and H. S. Gadhavi thank Sabine Eckhardt and Rona Thompson for help in running the FLEXPART model. K. Renuka thanks the European Science Foundation (ESF) Research Network TTORCH for supporting her participation in a FLEXPART training course. The authors thank the Department of Space, Government of India for funding the climate observatory operational at NARL, Gadanki. A. Stohl and Z. Klimont were supported by the European Union Seventh Framework Programme (FP7/2007-2013) under grant agreement no. 282688 - ECLIPSE. The authors would like to thank the two anonymous reviewers for their comments and suggestions, which helped to improve the manuscript.

Edited by: R. Krejci

\section{References}

Ackerman, A. S., Toon, O. B., Stevens, D. E., Heymsfield, A. J., Ramanathan, V., and Welton, E. J.: Reduction of Tropical Cloudiness by Soot, Science, 288, 1042-1047, doi:10.1126/science.288.5468.1042, 2000.

Amann, M., Bertok, I., Borken-Kleefeld, J., Cofala, J., Heyes, C., Höglund-Isaksson, L., Klimont, Z., Nguyen, B., Posch, M., Rafaj, P., Sandler, R., Schöpp, W., Wagner, F., and Winiwarter, W.: Cost-effective control of air quality and greenhouse gases in Europe: Modeling and policy applications, Environ. Modell. Softw., 26, 1489-1501, doi:10.1016/j.envsoft.2011.07.012, 2011.

Beegum, S., Moorthy, K. K., Babu, S., Satheesh, S., Vinoj, V., Badarinath, K., Safai, P., Devara, P., Singh, S., Vinod, Dumka, U. C., and Pant, P.: Spatial distribution of aerosol black carbon over India during pre-monsoon season, Atmos. Environ., 43, 10711078, doi:10.1016/j.atmosenv.2008.11.042, 2009.

Bergstrom, R. W., Pilewskie, P., Pommier, J., Rabbette, M., Russell, P. B., Schmid, B., Redemann, J., Higurashi, A., Nakajima, T., and Quinn, P. K.: Spectral absorption of solar radiation by aerosols during ACE-Asia, J. Geophys. Res.-Atmos., 109, D19S15, doi:10.1029/2003JD004467, 2004.

Bergstrom, R. W., Pilewskie, P., Russell, P. B., Redemann, J., Bond, T. C., Quinn, P. K., and Sierau, B.: Spectral absorption properties of atmospheric aerosols, Atmos. Chem. Phys., 7, 5937-5943, doi:10.5194/acp-7-5937-2007, 2007.

Bond, T. C., Streets, D. G., Yarber, K. F., Nelson, S. M., Woo, J.-H., and Klimont, Z.: A technology-based global inventory of black and organic carbon emissions from combustion, J. Geophys. Res.-Atmos., 109, D14203, doi:10.1029/2003JD003697, 2004.

Bond, T. C., Doherty, S. J., Fahey, D. W., Forster, P. M., Berntsen, T., DeAngelo, B. J., Flanner, M. G., Ghan, S., Kärcher, B., Koch, D., Kinne, S., Kondo, Y., Quinn, P. K., Sarofim, M. C., Schultz, M. G., Schulz, M., Venkataraman, C., Zhang, H., Zhang, S., Bellouin, N., Guttikunda, S. K., Hopke, P. K., Jacobson, M. Z., Kaiser, J. W., Klimont, Z., Lohmann, U., Schwarz, J. P., Shindell, D., Storelvmo, T., Warren, S. G., and Zender, C. S.: Bounding the role of black carbon in the climate system: A scientific assessment, J. Geophys. Res., 118, 5380-5552, doi:10.1002/jgrd.50171, 2013.

Clarke, A., Mcnaughton, C., Kapustin, V., Shinozuka, Y., Howell, S., Dibb, J., Zhou, J., Anderson, B., Brekhovskikh, V., Turner, H., and Pinkerton, M.: Biomass burning and pollution aerosol over North America: Organic components and their influence on spectral optical properties and humidification response, J. Geophys. Res.-Atmos., 112, D12S18, doi:10.1029/2006JD007777, 2007. 
Cooke, W. F., Liousse, C., Cachier, H., and Feichter, J.: Construction of a $1^{\circ} \times 1^{\circ}$ fossil fuel emission data set for carbonaceous aerosol and implementation and radiative impact in the ECHAM4 model, J. Geophys. Res., 104, 22137-22162, doi:10.1029/1999jd900187, 1999.

Davies, D. K., Ilavajhala, S., Wong, M. M., and Justice, C. O.: Fire Information for Resource Management System: Archiving and Distributing MODIS Active Fire Data, Geoscience and Remote Sensing, IEEE Transactions on, 47, 72-79, doi:10.1109/tgrs.2008.2002076, 2009.

Dickerson, R. R., Andreae, M. O., Campos, T., Mayol-Bracero, O. L., Neusuess, C., and Streets, D. G.: Analysis of black carbon and carbon monoxide observed over the Indian Ocean: Implications for emissions and photochemistry, J. Geophys. Res., 107, 8017, doi:10.1029/2001JD000501, 2002.

Fialho, P., Hansen, A., and Honrath, R.: Absorption coefficients by aerosols in remote areas: a new approach to decouple dust and black carbon absorption coefficients using sevenwavelength Aethalometer data, J. Aerosol Sci., 36, 267-282, doi:10.1016/j.jaerosci.2004.09.004, 2005.

Gadhavi, H. and Jayaraman, A.: Absorbing aerosols: contribution of biomass burning and implications for radiative forcing, Ann. Geophys., 28, 103-111, doi:10.5194/angeo-28-103-2010, 2010.

Ganguly, D., Jayaraman, A., Gadhavi, H., and Rajesh, T. A.: Features in wavelength dependence of aerosol absorption observed over central India, Geophys. Res. Lett., 32, L13821, doi:10.1029/2005GL023023, 2005.

Ganguly, D., Jayaraman, A., and Gadhavi, H.: Physical and optical properties of aerosols over an urban location in western India: Seasonal variabilities, J. Geophys. Res., 111, D24206, doi:10.1029/2006JD007392, 2006a.

Ganguly, D., Jayaraman, A., Rajesh, T. A., and Gadhavi, H.: Wintertime aerosol properties during foggy and nonfoggy days over urban center Delhi and their implications for shortwave radiative forcing, J. Geophys. Res., 111, D15217, doi:10.1029/2005JD007029, 2006b.

Ganguly, D., Ginoux, P., Ramaswamy, V., Winker, D. M., Holben, B. N., and Tripathi, S. N.: Retrieving the composition and concentration of aerosols over the Indo-Gangetic basin using CALIOP and AERONET data, Geophys. Res. Lett., 36, L13806, doi:10.1029/2009GL038315, 2009.

Giglio, L., Descloitres, J., Justice, C. O., and Kaufman, Y. J.: An Enhanced Contextual Fire Detection Algorithm for MODIS, Remote Sens. Environ., 87, 273-282, doi:10.1016/s00344257(03)00184-6, 2003.

Gustafsson, O., Krusa, M., Zencak, Z., Sheesley, R. J., Granat, L., Engstrom, E., Praveen, P. S., Rao, P. S. P., Leck, C., and Rodhe, H.: Brown Clouds over South Asia: Biomass or Fossil Fuel Combustion?, Science, 323, 495-498, doi:10.1126/science.1164857, 2009.

Hansen, A. D. A.: The Aethalometer, Berkeley, California, USA, available at: http://www.mageesci.com/images/stories/ docs/Aethalometer_book_2005.07.03.pdf (last access: 13 January 2015), 2005.

Haywood, J. M. and Ramaswamy, V.: Global sensitivity studies of the direct radiative forcing due to anthropogenic sulfate and black carbon aerosols, J. Geophys. Res., 103, 6043-6058, doi:10.1029/97JD03426, 1998.
Hertel, O., Christensen, J., Runge, E. H., Asman, W. A. H., Berkowicz, R., Hovmand, M. F., and Hov, O.: Development and testing of a new variable scale air pollution model - ACDEP, Atmos. Environ., 29, 1267-1290, 1995.

Jacobson, M. Z.: Strong radiative heating due to the mixing state of black carbon in atmospheric aerosols, Nature, 409, 695-697, doi:10.1038/35055518, 2001.

Jayaraman, A., Gadhavi, H., Ganguly, D., Misra, A., Ramachandran, S., and Rajesh, T. A.: Spatial variations in aerosol characteristics and regional radiative forcing over India: Measurements and modeling of 2004 road campaign experiment, Atmos. Environ., 40, 6504-6515, doi:10.1016/j.atmosenv.2006.01.034, 2006.

Joseph, S., Anitha, K., and Murthy, M. S. R.: Forest fire in India: a review of the knowledge base, J. For. Res.-JPN, 14, 127-134, doi:10.1007/s10310-009-0116-x, 2009.

Justice, C., Giglio, L., Boschetti, L., Roy, D., Csiszar, I., Morisette, J., and Kaufman, Y.: Algorithm Technical Background Document MODIS FIRE PRODUCTS, NASA, 2006.

Kirchstetter, T. W., Novakov, T., and Hobbs, P. V.: Evidence that the spectral dependence of light absorption by aerosols is affected by organic carbon, J. Geophys. Res.-Atmos., 109, D21208, doi:10.1029/2004JD004999, 2004.

Klimont, Z., Cofala, J., Xing, J., Wei, W., Zhang, C., Wang, S., Kejun, J., Bhandari, P., Mathur, R., Purohit, P., Rafaj, P., Chambers, A., Amann, M., and Hao, J.: Projections of $\mathrm{SO}_{2}, \mathrm{NO}_{\mathrm{x}}$ and carbonaceous aerosols emissions in Asia, Tellus B, 61, 602-617, doi:10.1111/j.1600-0889.2009.00428.x, 2009.

Klimont, Z., Kupiainen, K., Heyes, C., Cofala, J., Rafaj, P., Höglund-Isaksson, L., Borken, J., Schöpp, W., Winiwarter, W., Purohit, P., Bertok, I., and Sander, R.: ECLIPSE V4a: Global emission data set developed with the GAINS model for the period 2005 to 2050: key features and principal data sources, International Institute for Applied Systems Analysis (IIASA), Schlossplatz 1, 2361 Laxenburg, Austria, 8 pp., available at: http: //eccad.sedoo.fr/eccad_extract_interface/JSF/page_login.jsf (last access: 13 January 2015), 2013.

Klimont, Z., Hoglund, L., Heyes, C., Rafaj, P., Schoepp, W., Cofala, J., Borken-Kleefeld, J., Purohit, P., Kupiainen, K., Winiwarter, W., Amann, M., Zhao, B., Wang, S. X., Bertok, I., and Sander, R.: Global scenarios of air pollutants and methane: 1990-2050, in preparation, 2015a.

Klimont, Z., Kupiainen, K., Heyes, C., Purohit, P., Cofala, J., Rafaj, P., Borken-Kleefeld, J., and Schoepp, W.: Global anthropogenic emissions of particulate matter, in preparation, $2015 \mathrm{~b}$.

Kupiainen, K. and Klimont, Z.: Primary emissions of fine carbonaceous particles in Europe, Atmos. Environ., 41, 2156-2170, doi:10.1016/j.atmosenv.2006.10.066, 2007.

Lelieveld, J., Crutzen, P. J., Ramanathan, V., Andreae, M. O., Brenninkmeijer, C. A. M., Campos, T., Cass, G. R., Dickerson, R. R., Fischer, H., de Gouw, J. A., Hansel, A., Jefferson, A., Kley, D., de Laat, A. T. J., Lal, S., Lawrence, M. G., Lobert, J. M., Mayol-Bracero, O. L., Mitra, A. P., Novakov, T., Oltmans, S. J., Prather, K. A., Reiner, T., Rodhe, H., Scheeren, H. A., Sikka, D., and Williams, J.: The Indian Ocean Experiment: Widespread Air Pollution from South and Southeast Asia, Science, 291, 10311036, doi:10.1126/science.1057103, 2001.

McMahon, T. A. and Denison, P. J.: Empirical atmospheric deposition parameters - A survey, Atmos. Environ., 13, 571-585, doi:10.1016/0004-6981(79)90186-0, 1979. 
Moorthy, K. K., Beegum, S. N., Srivastava, N., Satheesh, S., Chin, M., Blond, N., Babu, S. S., and Singh, S.: Performance evaluation of chemistry transport models over India, Atmos. Environ., 71, 210-225, doi:10.1016/j.atmosenv.2013.01.056, 2013.

Nair, V. S., Solmon, F., Giorgi, F., Mariotti, L., Babu, S. S. S., and Moorthy, K. K.: Simulation of south asian aerosols for regional climate studies, J. Geophys. Res., 117, 1-17, doi:10.1029/2011JD016711, 2012.

National Center for Environmental Prediction/National Weather Service/NOAA/U.S. Department of Commerce: NCEP FNL Operational Model Global Tropospheric Analyses continuing from July 1999, Research Data Archive at the National Center for Atmospheric Research, 2000.

Pavuluri, C. M., Kawamura, K., Aggarwal, S. G., and Swaminathan, T.: Characteristics, seasonality and sources of carbonaceous and ionic components in the tropical aerosols from Indian region, Atmos. Chem. Phys., 11, 8215-8230, doi:10.5194/acp-11-82152011, 2011.

Raghavendra Kumar, K., Narasimhulu, K., Balakrishnaiah, G., Reddy, B. S. K., Gopal, K. R., Reddy, R. R., Satheesh, S. K., Moorthy, K. K., and Babu, S. S.: Characterization of aerosol black carbon over a tropical semi-arid region of Anantapur, India, Atmos. Res., 100, 12-27, doi:10.1016/j.atmosres.2010.12.009, 2011.

Ramachandran, S. and Kedia, S.: Black carbon aerosols over an urban region: Radiative forcing and climate impact, J. Geophys. Res., 115, D10202, doi:10.1029/2009JD013560, 2010.

Ramachandran, S. and Rajesh, T. A.: Black carbon aerosol mass concentrations over Ahmedabad, an urban location in western India: Comparison with urban sites in Asia, Europe, Canada, and the United States, J. Geophys. Res., 112, D06211, doi:10.1029/2006JD007488, 2007.

Sahu, S. K., Beig, G., and Sharma, C.: Decadal growth of black carbon emissions in India, Geophys. Res. Lett., 35, L02807, doi:10.1029/2007GL032333, 2008.

Schultz, M., Backman, L., Balkanski, Y., Bjoerndalsaeter, S., Brand, R., Burrows, J., Dalsoeren, S., de Vasconcelos, M., Grodtmann, B., Hauglustaine, D., Heil, A., Hoelzemann, J., Isaksen, I., Kaurola, J., Knorr, W., Ladstaetter-Weißenmayer, A., Mota, B., Oom, D., Pacyna, J., Panasiuk, D., Pereira, J., Pulles, T., Pyle, J., Rast, S., Richter, A., Savage, N., Schnadt, C., Schulz, M., Spessa, A., Staehelin, J., Sundet, J., Szopa, S., Thonicke, K., van het Bolscher, M., van Noije, T., van Velthoven, P., and A.F. Vik, F. W.: REanalysis of the TROpospheric chemical composition over the past 40 years (RETRO) - A long-term global modeling study of tropospheric chemistry: Final Report, Max Planck Institute for Meteorology, Hamburg, Julich/Hamburg, Germany, 126 pp., 2007.

Schultz, M. and Rast, S.: Emission data sets and methodologies for estimating emissions, Max Planck Institute for Meteorology, Hamburg, Hamburg, Germany, 77 pp., 2007.

Schultz, M. G., Heil, A., Hoelzemann, J. J., Spessa, A., Thonicke, K., Goldammer, J. G., Held, A. C., Pereira, J. M. C., and van het Bolscher, M.: Global wildland fire emissions from 1960 to 2000, Global. Biogeochem. Cy., 22, GB2002, doi:10.1029/2007gb003031, 2008 .
Seibert, P. and Frank, A.: Source-receptor matrix calculation with a Lagrangian particle dispersion model in backward mode, Atmos. Chem. Phys., 4, 51-63, doi:10.5194/acp-4-51-2004, 2004.

Sheesley, R. J., Kirillova, E., Andersson, A., Krusa, M., Praveen, P. S., Budhavant, K., Safai, P. D., Rao, P. S. P., and Gustafsson, Ö.: Year-round radiocarbon-based source apportionment of carbonaceous aerosols at two background sites in South Asia, J. Geophys. Res., 117, D10202, doi:10.1029/2011jd017161, 2012.

Stohl, A., Forster, C., Frank, A., Seibert, P., and Wotawa, G.: Technical note: The Lagrangian particle dispersion model FLEXPART version 6.2, Atmos. Chem. Phys., 5, 2461-2474, doi:10.5194/acp-5-2461-2005, 2005.

Stohl, A., Hittenberger, M., and Wotawa, G.: Validation of the lagrangian particle dispersion model FLEXPART against largescale tracer experiment data, Atmos. Environ., 32, 4245-4264, doi:10.1016/s1352-2310(98)00184-8, 1998.

Stohl, A., Klimont, Z., Eckhardt, S., Kupiainen, K., Shevchenko, V. P., Kopeikin, V. M., and Novigatsky, A. N.: Black carbon in the Arctic: the underestimated role of gas flaring and residential combustion emissions, Atmos. Chem. Phys., 13, 8833-8855, doi:10.5194/acp-13-8833-2013, 2013.

Suresh Babu, S. and Moorthy, K. K.: Aerosol black carbon over a tropical coastal station in India, Geophys. Res. Lett., 29, 2098, doi:10.1029/2002GL015662, 2002.

Suresh Babu, S., Satheesh, S. K., and Moorthy, K. K.: Aerosol radiative forcing due to enhanced black carbon at an urban site in India, Geophys. Res. Lett., 29, 1880, doi:10.1029/2002GL015826, 2002.

van der Werf, G. R., Randerson, J. T., Giglio, L., Collatz, G. J., Mu, M., Kasibhatla, P. S., Morton, D. C., DeFries, R. S., Jin, Y., and van Leeuwen, T. T.: Global fire emissions and the contribution of deforestation, savanna, forest, agricultural, and peat fires (19972009), Atmos. Chem. Phys., 10, 11707-11735, doi:10.5194/acp10-11707-2010, 2010.

Venkataraman, C., Habib, G., Eiguren-Fernandez, A., Miguel, A. H., and Friedlander, S. K.: Residential Biofuels in South Asia: Carbonaceous Aerosol Emissions and Climate Impacts, Science, 307, 1454-1456, doi:10.1126/science.1104359, 2005.

Vinoj, V., Satheesh, S. K., and Moorthy, K. K.: Optical, radiative, and source characteristics of aerosols at Minicoy, a remote island in the southern Arabian Sea, J. Geophys. Res., 115, D01201, doi:10.1029/2009JD011810, 2010.

Yasa, Z., Amer, N. M., Rosen, H., Hansen, A. D. A., and Novakov, T.: Photoacoustic investigation of urban aerosol particles, Appl Opt., 18, 2528-2530, doi:10.1364/AO.18.002528, 1979.

Zhang, X. Y., Wang, Y. Q., Zhang, X. C., Guo, W., Niu, T., Gong, S. L., Yin, Y., Zhao, P., Jin, J. L., and Yu, M.: Aerosol monitoring at multiple locations in China: contributions of EC and dust to aerosol light absorption, Tellus B, 60, 647-656, doi:10.1111/j.1600-0889.2008.00359.x, 2008. 